4. Sen R, Gupta S, Batra A, Gill M, Gupta V, Marwah N. Acute lymphoblastic leukaemia (ALL) with infiltration of the thyroid: a cytological diagnosis. Endocr Pathol 2012;23:268-269.

5. Valizadeh M, Moghimi M, Feizi A, Radmand F, Piri Z. Thyroid nodule in an eighteen-year-old man as the first presentation of acute lymphoblastic leukemia. Int J Endocrinol Metab 2014;12:e17364.

Address for Correspondence: Füsun ÖZDEMIRKIRAN, M.D.,

Katip Çelebi University Faculty of Medicine, Atatürk Training and Research Hospital,

Clinic of Hematology, İzmir, Turkey

E-mail: fusun75@gmail.com

Received/Geliş tarihi: March 27, 2015

Accepted/Kabul tarihi: April 13, 2015

DOI: $10.4274 /$ tjh. 2015.0136

\section{Auer Rods in Chronic Myelomonocytic Leukemia Can Change the Diagnosis}

\section{Kronik Miyelomonositik Lösemide Auer Çubukları Tanıyı Değiştirebilir}

\section{To the Editor,}

Chronic myelomonocytic leukemia (CMML) is a clonal hematopoietic stem cell disorder with overlapping morphological features of myelodysplastic and myeloproliferative disease and a potential risk of transformation to acute myeloid leukemia. Presence of Auer rods in CMML is a rare finding and the presence of an occasional Auer rod gives the diagnosis of CMML-2 in spite of the presence of $<5 \%$ blasts in peripheral blood/bone marrow [1,2]. A 39-year-old female, diagnosed outside our facility with Crohn's disease, presented with severe anemia with weakness and fatigue for 1 month. The patient had been treated previously with prednisolone at $1 \mathrm{mg} / \mathrm{kg} /$ day. Diarrhea was resolved after 2 weeks of therapy. Steroid dose was reduced and stopped after 4 months. There were no bowel symptoms and the colonoscopy done at our institution was normal. Hemoglobin was $65 \mathrm{~g} / \mathrm{L}$, total leukocyte count was $16.4 \times 109 / \mathrm{L}$, and platelet count was $192 \times 109 / \mathrm{L}$. Peripheral blood smear showed $4 \%$ blasts and promonocytes, 3\% myelocytes and metamyelocytes, 26\% monocytes (including abnormal forms) (Figures $1 \mathrm{~A}$ and $1 \mathrm{~B}$ ), and 2 nucleated red blood cells/100 white blood cells. Bone marrow aspirate was hypercellular with dyspoiesis in all 3 lineages with increased monocytic cells (Figures 1C and 1D). Erythroid series showed predominantly megaloblastoid erythropoiesis with nuclear budding, multinuclearity, and cytoplasmic vacuolation. Granulocytic series showed myeloid hyperplasia with 15\%-20\% monocytes, $2 \%$ basophils, and 4\% blasts, with an occasional blast showing an Auer rod (Figure 1C, arrows). Micromegakaryocytes and megakaryocytes with abnormal lobation and multinucleation were seen. Bone marrow biopsy was hypercellular (100\%) with grade 1 reticulin fibrosis. Megakaryocytes were increased in number and showed hypolobation and multinucleation. Conventional cytogenetics showed a normal female karyotype. There was no Philadelphia chromosome or BCR/ABL fusion gene. Overall features were compatible with a diagnosis of CMML type 2. She was started on $3+7$ induction chemotherapy using daunorubicin and ara-C. Bone marrow aspirate done on day 28 confirmed morphological complete remission. She underwent HLA-identical allogeneic hematopoietic stem cell transplantation from her elder brother and currently (2 years posttransplant) continues to be disease-free. Auer rods are a hallmark of acute myeloid leukemia but are occasionally seen in myelodysplastic syndrome (refractory anemia with excess blasts type 2) or CMML cases, and rarely in patients with fewer than $5 \%$ blasts $[3,4]$. According to the World Health Organization 2008 diagnostic criteria, the presence of Auer rods fulfills the criteria for CMML-2 irrespective of the blast count [5]. Thus, in CMML, a thorough search for Auer rods should be done for a correct diagnosis as the treatment given for CMML-2 is different from that for CMML-1 and the risk of transformation to acute leukemia is greater. We also want to emphasize that the presence of Auer rods with fewer than $5 \%$ blasts is a rare phenomenon that seems to be clinically, morphologically, and cytogenetically heterogeneous, and it could be a valuable finding for early treatment options in patients with CMML-2 if there is a HLA-identical donor.

\section{Conflict of Interest Statement}

The author of this paper has no conflict of interest, including specific financial interests, relationships, and/ or affiliations relevant to the subject matter or materials included in this manuscript.

Key Words: Auer rod, Chronic myelomonocytic leukemia, Hematopoietic stem cell transplantation

Anahtar Sözcükler:Auer çubukları, Kronikmiyelomonositik lösemi, Hematopoetik kök hücre transplantasyonu

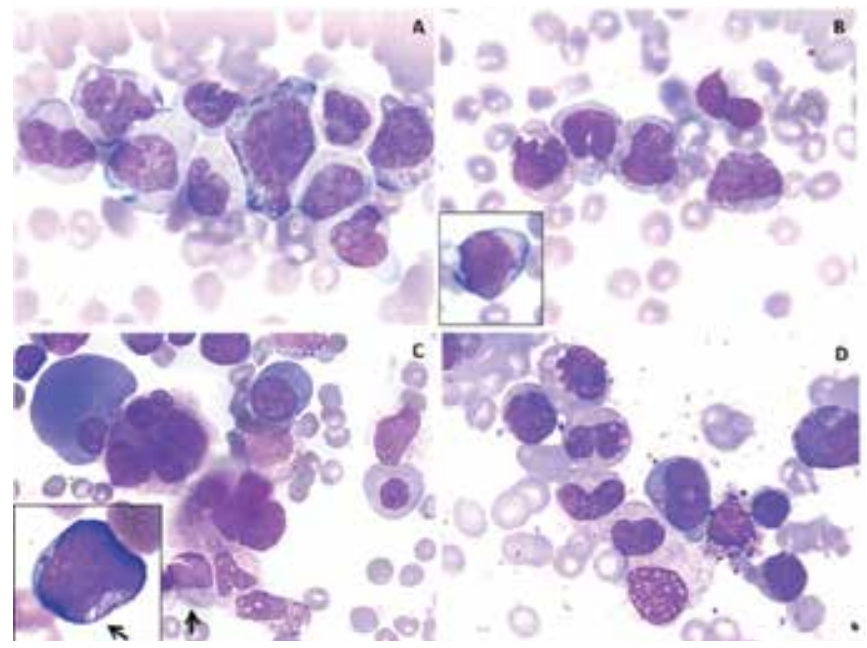

Figure 1. A, B) Peripheral blood smear showing presence of abnormal monocytes along with myelocytes and blast (B- inset). C, D) Bone marrow aspirate showing dyspoiesis in all three lineages (C) with an occasional blast showing an Auer rod (C, arrows) with increased monocytic cells (D) (Jenner and Giemsa stain, 1000x). 
Smeeta Gajendra1, Ranjit Kumar Sahoo ${ }^{2}$

${ }^{1}$ Medanta-The Medicity, Department of Pathology and Laboratory Medicine, Haryana, India

${ }^{2}$ All India Institute of Medical Sciences, Department of Medical Oncology, New Delhi, India

\section{References}

1. Patnaik MM, Parikh SA, Hanson CA, Tefferi A. Chronic myelomonocytic leukaemia: a concise clinical and pathophysiological review. Br J Haematol 2014;165:273-286.

2. $\mathrm{Xu} \mathrm{Z}$, Shier L. Auer rods in a patient with chronic myelomonocytic leukemia type 2. Blood 2014;124:3828.

3. Willis MS, McKenna RW, Peterson LC, Coad JE, Kroft SH. Low blast count myeloid disorders with Auer rods: a clinicopathologic analysis of 9 cases. Am J Clin Pathol 2005;124:191-198.

4. Germing U, Strupp C, Kuendgen A, Aivado M, Giagounidis A, Hildebrandt B, Aul C, Haas R, Gattermann N. Refractory anaemia with excess of blasts (RAEB): analysis of reclassification according to the WHO proposals. Br J Haematol 2006;132:162-167.

5. Orazi A, Bennett JM, Germing U, Brunning RD, Bain BJ, Thiele J. Chronic myelomonocytic leukemia. In: Swerdlow SH, Campo E, Harris NL, Jaffe ES, Pileri SA, Stein H, Thiele J, Vardiman JW, (eds). WHO Classification of Tumours of Haematopoietic and Lymphoid Tissues. 4th ed. Lyon, France, IARC Press, 2008.

Address for Correspondence: Smeeta GAJENDRA, M.D.,

Medanta-the Medicity, Department of Pathology and Laboratory Medicine, Haryana, India Phone: +90 09013590875 E-mail: drsmeeta@gmail.com

Received/Gelis tarihi: April 7, 2015

Accepted/Kabul tarihi: April 16, 2015

DOI: $10.4274 /$ tjh.2015.0148

\section{A Case of Acquired Thrombotic Thrombocytopenic Purpura: Three Recurrences in 25 Years}

Kazanilmış Trombotik Trombositopenik Purpura Olgusu: 25 Yillık Takipte Üç Rekürens

\section{To the Editor,}

A 60-year-old woman with fever, lassitude, neurological symptoms, hematuria, subconjunctival bleeding, several ecchymoses, reticulocytosis, microangiopathic hemolytic anemia (with burr cells, schistocytes, and spherocytes), and thrombocytopenia was first seen in the neurology clinic in 1985. Because of her normal cerebrospinal fluid and unremarkable MRI findings with some nonspecific EEG findings, thrombotic thrombocytopenic purpura (TTP) was diagnosed based on her clinical and microangiopathic hemolytic anemia findings, as reported previously. Her
Coombs' test and kidney and liver function results were almost normal and her moribund condition was treated with megadose methylprednisolone (MDMP) [1,2,3]. Her platelet count became normal on the fourth day of treatment; she did not require any blood transfusions and all clinical and laboratory findings were improved. Thereafter, she was seen once a year. Informed consent was obtained.

Fifteen years later, at the age of 75 , her symptoms recurred with angiopathic findings without known infection, drug use, mild hematuria, or urinary system infection (E. coli above $100,000 / \mathrm{mL}$ ). She was diagnosed with recurrence of TTP and was treated with antibiotics and oral MDMP (30 $\mathrm{mg} / \mathrm{kg}$ for 3 days and then $20 \mathrm{mg} / \mathrm{kg}$ for 4 days; subsequently at doses of $10,5,2$, and $1 \mathrm{mg} / \mathrm{kg}$ each for 1 week in duration), given once around 6 a.m. Her symptoms improved in terms of anemia and microangiopathic laboratory findings, including the thrombocytopenia, within a week without admission to the hospital. Her liver and kidney functions (urea: $30 \mathrm{mg} /$ $\mathrm{dL}$, creatinine: less than $1.1 \mathrm{mg} / \mathrm{dL}$ ) stayed normal.

In 2007, 22 years after the first attack and at the age of 82, she had another episode of microangiopathic hemolytic anemia and thrombocytopenia without a known cause. She was being treated again with oral MDMP as of the year 2000. She responded in a 1 -week period and stayed symptom-free for 3 years. Later it was learned that she had died at home at the age of 85 due to heart failure.

Thrombotic microangiopathic syndromes, though rare, have diverse pathophysiological pathways that can lead to microangiopathic anemia, a procoagulant state with or without damage to the kidneys and other organs, and could be acquired or hereditary $[4,5]$.

Hereditary conditions related to hereditary ADAMTS 13 deficiency, complement $\mathrm{H}$ factor $(\mathrm{CFH})$, complement 3-3b, complement C factor 1 (CF 1 or CD 45), cobalamin $\mathrm{C}$ disease, and some of the coagulation disorders such as thrombomodulin, plasminogen, and protein kinase $\mathrm{C}$ deficiencies could not be considered in this patient because of her age (first attack at about 60 years of age). Among the acquired disorders, Shiga toxin-mediated hemolytic and uremic syndrome (HUS), HELLP syndrome, drug immune-mediated conditions, and pregnancy-related microangiopathic syndromes could easily be rejected because of her age and no known drug history.

Although ADAMTS 13 deficiency related to antibodies was not studied (it was not known in 1985 when the patient was first seen), and permission for its determination could not be obtained for the patient's second and third flare-ups, it was the most likely diagnosis for our patient at the time to our knowledge. MDMP was given intravenously during the first attack while she was in the hospital. On the second and third recurrences, it was administered orally at home. 